The University of Maine

\title{
DigitalCommons@UMaine
}

Earth Science Faculty Scholarship

Earth Sciences

3-1-1990

\section{Serendibite from the Northwest Adirondack Lowlands, in Russell, New York, USA}

Edward S. Grew

University of Maine - Main, esgrew@maine.edu

Martin G. Yates

William deLorraine

Follow this and additional works at: https://digitalcommons.library.umaine.edu/ers_facpub Part of the Earth Sciences Commons

\section{Repository Citation}

Grew, Edward S.; Yates, Martin G.; and deLorraine, William, "Serendibite from the Northwest Adirondack Lowlands, in Russell, New York, USA" (1990). Earth Science Faculty Scholarship. 163.

https://digitalcommons.library.umaine.edu/ers_facpub/163 
$\left(\mathrm{Me}_{75-83}\right)$, aluminous diopside, green amphibole, colourless spinel, large poikilitic blue tourmaline, and a little calcite. Tourmaline includes several minerals, especially clinopyroxene, spinel, and a few small crystals of serendibite. Scattered grains of the latter in one crystal of tourmaline are in optical continuity, suggesting that tourmaline is a breakdown product after serendibite. The serendibite is colourless to very light green. The mineral is much less coloured than the prussian blue crystals in a calcsilicate rock associated with clintonite clinopyroxenites from Ianapera, in SW Madagascar (Nicollet, 1988, 1990). The Ihosy serendibite has low birefringence and fine polysynthetic twinning. It may be mistaken for sapphirine, but it is distinguishable from the latter by a larger extinction angle and by its occurrence in calcic rocks. The ferromagnesian minerals in the rock are magnesium rich. Tourmaline (Table 1 ) is a magnesian uvite and the $X_{\mathrm{Mg}}$ ratio of the spinel is greater than 0.9 . Hornblende and clinopyroxene are close to their $\mathrm{Mg}$ end-members $\left(X_{\mathrm{Mg}} \approx 0.97\right)$. The $\mathrm{Fe}-\mathrm{Mg}$ partitioning between tourmaline and serendibite $\left(K_{\mathrm{d}}\right)$ is $\approx 0.4$ as in the more iron rich pair from Ianapera; it is lower than the $K_{\mathrm{d}}$ of coexisting tourmaline and serendibite from Melville Peninsula, Canada $\left(\mathrm{K}_{\mathrm{d}}=0.61\right.$ : Hutcheon et al., 1977).

The $P-T$ conditions of the crystallization of this rock are similar to those estimated for the neighbouring seven-phase anatectic gneisses (Nicollet, 1988).
Acknowledgements. This work was supported by contracts CNRS-INSU 89 DBT V-11 and DBT 96.

\section{References}

de Roever, W. F. and Kieft, C. (1976) Am. Mineral. 61, 332-3

Grew. E. S. (1983) Mineral. Mag. 47, 401-3.

- (1988) Am. Mineral. 73, 345-57.

Haslam, H. W. (1980) Mineral. Mag. 43, 822-3.

Huijsmans, J. P. P., Barton, M., and van Bergen, M. J. (1982) Neues Jahrb. Mineral. Abh. 143, 249-61.

Hutcheon, I., Gunter, A. E. and Lecheminant, A. N. (1977) Can. Mineral. 15, 108-12.

Lee, S. M. and Holdaway, M. J. (1977) Geophys. Monogr. 20, 79-94.

Lonker, S. W. (1988) Contrib. Mineral. Petrol. 98 $502-16$.

Mégerlin, N. (1968) C.R. Sem. Géol. Madagascar, 67-9. Nicollet, C. (1985) Précambr. Res. 28, 175-85. (1988) Thèse d'Etat. Clermont Fd, 350pp.

- (1990) In Granulites and Crustal Differentiation (Vielzeuf, D. and Vidal, P., eds.), Kluwer Academic publishers, in press.

Semroud, B., Fabriès, J., and Conquéré, F. (1976) Bull. Soc. fr. Mineral. Cristallogr. 99, 58-60.

van Bergen, M. J. (1980) Mineral. Mag. 43, 651-8.

von Knorring, O. V., Sahama, T. G., and Lehtinen, M. (1969) Bull. Geol. Soc. Finland, 41, 79-84.

[Manuscript received 2 June 1989; revised 13 July 1989$]$

(C) Copyright the Mineralogical Society

KEYWORDS: grandidierite, serendibite, tourmaline, Ihosy, Madagascar, metamorphism.

Département de Géologie, UA 10 ,

5 Rue Kessler, Clermont Fd, 63038, France

Christian Nicollet

MINERALOGICAL MAGAZINE, MARCH 1990, VOL. 54, PP. 133-136

\section{Serendibite from the northwest Adirondack Lowlands, in Russell, New York, USA}

SERENDIBITE, to a first approximation, $\mathrm{Ca}_{2}(\mathrm{Mg}$, $\left.\mathrm{Fe}^{2+}\right)_{3}\left(\mathrm{Al}, \mathrm{Fe}^{3+}\right)_{4.5} \mathrm{~B}_{1.5} \mathrm{Si}_{3} \mathrm{O}_{20}$, has been reported from about eight localities worldwide (Deer $\mathrm{et}$ al., 1978; Nicollet, 1988), including Johnsburg, New York, in the southern Adirondack Highlands (Larsen and Schaller, 1932; Grew et al., in press). It is a mineral of high-temperature calc-silicate skarns, mostly in the granulite-facies. In this paper we report a new occurrence from the northwest Adirondacks Lowlands. This occurrence has many mineralogical and chemical features in common with the serendibite-diopside rocks in the Johnsburg deposit, although located $130 \mathrm{~km}$ distant.

Serendibite occurs in core from hole 1872 drilled by St. Joe Resources Company (presently 
Zinc Corporation of America) near Cassidy Road, $350 \mathrm{~m}$ south of Town Line Road, town of Russell, NY $\left(44^{\circ} 31^{\prime} \mathrm{N}, 75^{\circ} 09^{\prime} \mathrm{E}\right)$. The drill hole penetrated calc-silicate rocks and marbles typical of the northwest Adirondack Lowlands (e.g. Bohlen et al., 1985). A summary of the core log to $40 \mathrm{~m}$ is as follows (compositional layering intersected at high angle by the vertical core).

0-6m: Overburden.

6-8.5 m: Biotite-diopside calc-silicate granulites (e.g. at $7 \mathrm{~m}$, plagioclase-biotite-titanitehornblende-diopside)

8.5-30 m: Diopside granulite with disseminated $\mathrm{cm}$-sized books of phlogopite, alternating with amphibole-phlogopite rock at $16.8 \mathrm{~m}$, serendibite-diopside rock at $17.7 \mathrm{~m}$, and finely layered quartz-rich diopside-K-feldspar-titanite granulite at $22-25 \mathrm{~m}$.

30-37.5 m: Dolomite-calcite marble with serpentine (after forsterite?), minor spinel and phlogopite.

37.5-40 m: Diopside-rich granulite.

The serendibite-diopside rock occurs over an interval of $13-20 \mathrm{~cm}$ (largest core fragment is $5 \mathrm{~cm}$ long). Recovery of the core was not complete and we are not able to fully characterise the layering in this section of the core. The closest rocks to the serendibite-diopside rock are diopside granulite with phlogopite books at $0.6 \mathrm{~m}$ below and amphibole-phlogopite rock at $0.9 \mathrm{~m}$ above. The latter is a relatively coarse intergrowth of phlogopite and calcic clinoamphibole in which diopside occurs sporadically, mostly included in the amphibole.

Important constituents of the serendibite-diopside rock are apatite, calcite, pargasite, and secondary phyllosilicates resembling sericite and chlorite, while scapolite, tourmaline, grandidierite, phlogopite, sulfide, sinhalite (?), and spinel are rare. Serendibite is deep blue in hand specimen, while in thin section it forms pale-blue polysynthetically twinned grains up to $1 \mathrm{~cm}$ across with highly irregular outlines. Preferred orientation of the grains is implied by parallelism of the twin lamellae from grain to grain. Serendibite is partly replaced by a birefringent material in which traces of the twinning lamallae are preserved. A similar material replaces serendibite at Johnsburg (Grew et al., in press). Diopside occurs as inclusions in serendibite and as a granular matrix (grains mostly $\leqslant 0.5 \mathrm{~cm}$ ) to it. Patches and overgrowths of pargasite are locally developed in and around diopside, most commonly along contacts with serendibite. Apatite is relatively coarse-grained $(\leqslant 0.5 \mathrm{~cm})$. Larger calcite grains $(1-4 \mathrm{~mm})$ are mantled and penetrated by a phyllosilicate; these intergrowths may have resulted from alteration of scapolite. Fresh scapolite in grains $\leqslant 1 \mathrm{~mm}$ across occurs sparingly in and between diopside or calcite and serendibite. Grandidierite, spinel, and phlogopite occur in trace amounts within serendibite and appear to have formed from serendibite breakdown. Tourmaline forms irregular, poikilitic patches around serendibite and in places, margins around apatite enclosed in serendibite. A mineral tentatively identified as sinhalite occurs with spinel in serendibite.

Textures suggest a 3-stage history for the serendibite-diopside rock: (1) primary serendibitediopside \pm scapolite-apatite assemblages; (2) secondary assemblages with grandidierite, tourmaline, pargasite, spinel and/or phlogopite which could have formed by reactions such as serendibite + diopside $+\mathrm{Na}_{2} \mathrm{O}+\mathrm{K}_{2} \mathrm{O}+\mathrm{H}_{2} \mathrm{O}+\mathrm{CO}_{2}$ $=$ grandidierite + pargasite + calcite $+\mathrm{B}_{2} \mathrm{O}_{3}$ (see Grew et al., in press); and (3) alteration to finegrained phyllosilicates. The stage 2 minerals, notably grandidierite, are also characteristic of the Johnsburg serendibite-diopside rocks and thus we infer that a second high-temperature event affected the Russell locality. Conditions of formation of the primary serendibite-diopside assemblage could be $660-750^{\circ} \mathrm{C}$ and $6.7-7.4 \mathrm{kbar}$, values estimated at nearby localities (maps of Bohlen et al., 1985; Edwards and Essene's, 1988, $700^{\circ} \mathrm{C}$ isotherm passes close to the locality), and consistent with conditions inferred for serendibite at other localities (Grew et al., in press). The core was drilled about $1 \mathrm{~km}$ northwest of Buddington's (1963) isograd marking the northern limit for orthopyroxene in amphibolite, implying near granulite-facies conditions for serendibite at Russell, that is, somewhat lower temperatures than the clearly granulite-facies Johnsburg deposit.

Serendibite and associated minerals (1-2 grains each) were analysed with a wavelength-dispersive MAC 400s electron microprobe at the University of Maine (procedure of Yates and Howd, 1988) (Table 1). Assuming that the boron content is similar to the values measured in the Johnsburg serendibite (Grew et al, , in press), analytical totals for serendibite are reasonable and the formulae approach $\mathrm{Ca}_{2}(\mathrm{Mg}, \mathrm{Fe})_{3} \mathrm{Al}_{4,5} \mathrm{~B}_{1,5} \mathrm{Si}_{3} \mathrm{O}_{20}$. Compositions of the two analysed grains can be related by the Tschermaks substitution $(\mathrm{Mg}, \mathrm{Fe})+\mathrm{Si}=2$ Al. Compared to serendibite from most other localities (Deer et al., 1978); Nicollet, 1988), the Russell serendibites are magnesian and sodian, but less so than the Johnsburg serendibites. Incorporation of $\mathrm{Na}$ in the Russell and Johnsburg serendibites appears to be through the substitution $\mathrm{Na}+\mathrm{Si}=\mathrm{Ca}+\mathrm{Al}$, which is characteristic of the related minerals aenigmatite and rhönite (Deer et al., 1978). Diopside compositions are also 


\begin{tabular}{|c|c|c|c|c|c|c|c|}
\hline \multirow{2}{*}{$\begin{array}{l}\text { Mineral } \\
\text { Grain }\end{array}$} & \multicolumn{2}{|c|}{ Serendibite } & \multicolumn{2}{|c|}{ Diopside } & \multirow[t]{2}{*}{ Pargasite } & \multirow[t]{2}{*}{ Scapolite } & \multirow[t]{2}{*}{ Grandidicritc } \\
\hline & 1 & 2 & 1 & 2 & & & \\
\hline \multicolumn{8}{|c|}{ Wcight Percemt } \\
\hline $\mathrm{SiO}_{2}$ & 24.05 & 25.35 & 52.09 & 53.63 & 43.10 & 46.73 & 20.81 \\
\hline $\mathrm{TiO}_{2}^{2}$ & 0.02 & 0.04 & 0.06 & 0.07 & 0.30 & nd. & .03 \\
\hline $\mathrm{Al}_{2} \mathrm{O}_{3}$ & 35.76 & 34.04 & 4.58 & 3.35 & 16.69 & 26.41 & 52.03 \\
\hline $\mathrm{FeO}$ & 1.94 & 2.10 & 1.07 & 1.09 & 2.09 & 0.17 & 1.14 \\
\hline $\mathrm{MnO}$ & 0.05 & 0.09 & 0.16 & 0.12 & 0.01 & nd. & 0.06 \\
\hline $\mathrm{MgO}$ & 15.34 & 15.49 & 16.84 & 17.51 & 18.94 & nd. & 13.08 \\
\hline $\mathrm{COO}$ & 14.22 & 14.39 & 23.93 & 23.65 & 12.75 & 16.31 & 0.07 \\
\hline $\mathrm{Na}_{2} \mathrm{O}$ & 0.50 & 0.63 & 0.40 & 0.54 & 2.74 & 4.10 & 0.01 \\
\hline $\mathrm{K}_{2} \mathrm{O}$ & 0.00 & 0.00 & 0.02 & 0.04 & 1.40 & 0.16 & 0.05 \\
\hline $\mathrm{Cl}^{2}$ & nd. & nd. & nd. & nd. & nd. & 0.50 & nd. \\
\hline $\mathrm{SO}_{3}$ & nd. & nd. & nd. & nd & $\mathbf{n d}$. & 1.08 & nd \\
\hline $\mathrm{B}_{2} \mathrm{O}_{3}$ & $7.43^{*}$ & $7.44^{*}$ & nd. & nd. & nd. & nd. & $11.92^{*}$ \\
\hline $\mathrm{co}_{2}$ & nd. & nd. & nd. & nd. & nd. & $3.54^{*}$ & nd. \\
\hline $\mathrm{H}_{2} \mathrm{O}$ & nd. & nd. & nd. & nd. & $2.13^{*}$ & nd. & nd. \\
\hline Total & 99.31 & 99.57 & 99.15 & 100.00 & 100.15 & $98.89+$ & 99.20 \\
\hline \multicolumn{8}{|c|}{ Calions } \\
\hline Oxygens & 20 & 20 & 6 & 6 & 24 & $(\mathrm{Si}+\mathrm{Al}=12)$ & 9 \\
\hline Si & 2.811 & 2.962 & 1.899 & 1.935 & 6.068 & 7.203 & 1.012 \\
\hline $\mathrm{Al}$ & 1.689 & 1.538 & 0.101 & 0.065 & 1.932 & 4.797 & nd. \\
\hline B & $1.500^{*}$ & $1.500^{*}$ & nd. & nd. & nd. & nd. & $1.000^{*}, \#$ \\
\hline Total & 6.000 & 6.000 & 2.000 & 2.000 & 8.000 & 12.000 & 2.012 \\
\hline $\mathrm{Ti}$ & 0.002 & 0.004 & 0.002 & 0.002 & 0.032 & nd. & 0.001 \\
\hline Al & 3.238 & 3.150 & 0.096 & 0.077 & 0.837 & 0.000 & 2.981 \\
\hline $\mathrm{Fe}$ & 0.190 & 0.205 & 0.033 & 0.033 & 0.246 & 0.022 & 0.046 \\
\hline $\mathrm{Mn}$ & 0.005 & 0.009 & 0.005 & 0.004 & 0.001 & nd. & 0.002 \\
\hline $\mathbf{M g}$ & 2.673 & 2.699 & 0.915 & 0.942 & 3.975 & nd. & 0.948 \\
\hline Total & 6.108 & 6.067 & 1.051 & 1.058 & 5.091 & 0.022 & 3.978 \\
\hline $\mathrm{Ca}$ & 1.809 & 1.802 & 0.935 & 0.914 & $i .923$ & 2.693 & 0.004 \\
\hline $\mathrm{Na}$ & 0.113 & 0.143 & 0.028 & 0.038 & 0.748 & 1.225 & 0.001 \\
\hline $\mathrm{K}$ & 0.000 & 0.000 & 0.001 & 0.002 & 0.251 & 0.031 & 0.003 \\
\hline Total & 1.922 & 1.945 & 0.964 & 0.954 & 2.922 & 3.949 & 0.008 \\
\hline Tolal Cations & 14.030 & 14.012 & 4.015 & 4.012 & 16.013 & 15.971 & 5.998 \\
\hline \multicolumn{8}{|c|}{ Anions } \\
\hline $\mathrm{OH}$ & $\mathrm{nd}$. & nd. & nd. & nd. & $2,000^{*}$ & nd. & nd. \\
\hline $\mathrm{CO}_{3}$ & nd. & nd. & nd. & nd. & $n d$ & $0.744^{*}$ & nd. \\
\hline $\mathrm{SO}_{4}$ & nd. & nd. & nd. & nd. & nd. & 0.125 & nd. \\
\hline $\mathrm{Cl}^{+}$ & nd. & nd. & nd. & nd. & nd. & 0.131 & nd. \\
\hline Total Anions & & & & & 2,000 & 1.000 & \\
\hline
\end{tabular}

* Calculated Value: \# Trigonally Coordinated: + Tolal sonected for $\mathrm{Cl}=\mathrm{O}$;

nd. - not determined or calculated.

related by the Tschermaks substitution. It was not possible to obtain satisfactory analyses of either tourmaline or spinel. Rough values for tourmaline are 34-35 wt. $\% \mathrm{SiO}_{2}, 0 \% \mathrm{TiO}_{2}, 31-32 \% \mathrm{Al}_{2} \mathrm{O}_{3}$, $1 \% \mathrm{FeO}, 12 \% \mathrm{MgO}, 3.4 \% \mathrm{CaO}, 1.3 \% \mathrm{Na}_{2} \mathrm{O}$. One spinel is $\mathrm{Mg}_{0.9} \mathrm{Fe}_{0.1} \mathrm{Al}_{2} \mathrm{O}_{4}$. In terms of $\mathrm{Mg} / \mathrm{Fe}$ ratio, the minerals increase as follows: spinel $<$ serendibite $<$ pargasite $<$ grandidierite $<$ diopside, and $\mathrm{Na} / \mathrm{Ca}$ ratio: diopside $<$ serendibite $\ll$ pargasite $<$ scapolite.

We suggest that the serendibite-diopside rock results from the metamorphism of boron-bearing sediments of evaporitic affinities. The marblecalc-silicate unit that was penetrated by hole 1872 locally hosts anhydrite-rich rocks of probable evaporitic origin. Similar rocks are exposed in the Balmat and Edwards Mines 20 to $30 \mathrm{~km}$ away. Moreover, Swihart and Moore (1989) reported that boron isotope compositions of tourmaline in calc-silicate rocks from other localities in the northwest Adirondack Lowlands lie between isotope compositions of boron from normal marine sediments and present-day seawater. Consequently we have reason to infer a marine sedimentary origin, rather than an igneous origin, for the boron in the Russell serendibite. It is possible that the serendibite-diopside rock developed by isochemical metamorphism of a boron-rich calcareous sediment. However, certain features suggest that limited metasomatism may have also played a role in its formation. In particular, the Russell serendibite-diopside rock closely resembles the serendibite-diopside zone in the metasomatic sequence developed between $\mathrm{K}$ feldspar rock and marble at the Johnsburg locality. Such metasomatic rocks are characterized by a simple mineralogy although the number of constituents (components) in the rock is fairly large. Only 3 or 4 phases in the Russell rock formed during the first metamorphic stage, but 7 non- 
volatile components are needed to describe the phases (serendibite, diopside, apatite, and scapolite): $\mathrm{CaO}, \mathrm{Na}_{2} \mathrm{O}, \mathrm{MgO}, \mathrm{Al}_{2} \mathrm{O}_{3}, \mathrm{SiO}_{2}, \mathrm{~B}_{2} \mathrm{O}_{3}$, and $\mathrm{P}_{2} \mathrm{O}_{5}$ (phase rule would allow 7 phases to be stable). By analogy with Johnsburg, we suspect that the constituents in the Russell rocks were mobilized, though possibly over distances of $1 \mathrm{~m}$ or less. Nonetheless, even such limited mobilization may have been sufficient to concentrate dispersed boron into a thin boron-rich serendibite-diopside rock.

Acknowledgements. We thank Prof. Brad van Diver, State University of New York at Potsdam, for originally identifying the serendibite. This research is supported by US National Science Foundation grant DPP8613241.

\section{References}

Bohlen, S. R., Valley, J. W. and Essene, E. J. (1985) J. Petrol. 26, 971-92.

Buddington, A. F. (1963) Geol. Soc. Am. Bull. 74, 1155-82.
Deer, W. A., Howie, R. A. and Zussman, J. (1978) Rock-forming minerals, vol. 2A, Single-chain silicates, 2nd Ed., Wiley, New York.

Edwards, R. L. and Essene, E. J. (1988) J. Petrol. 29, $39-72$.

Grew, E. S., Yates. M. G., Swihart, G. H., Moore, P. B. and Marquez, N. (in press) In Progress in metamorphic and magmatic petrology. (L. L. Perchuk, Ed.). Cambridge University Press.

Larsen, E. S. and Schaller, W. T. (1932) Am. Mineral. 17, 457-65.

Nicollet, C. (1988) Métabasites granulitiques, anorthosites et roches associées de la croûte inférieure. Exemples pris à Madagascar et dans le Massif Central français. Arguments en faveur d'un métamorphisme associé à l'extension lithosphérique. Thése d'Etat. Université Blaise Pascal, Clermont-Ferrand.

Swihart, G. H. and Moore, P. B. (1989) Geochim Cosmochim. Acta, 53, 911-16.

Yates, M. G. and Howd, F. H. (1988) Maritime Sediments and Atlantic Geology, 24, 267-79.

[Manuscript received 3 July 1989; revised 22 August 1989]

(C) Copyright the Mineralogical Society

KeYwords: serendibite, diopside, Adirondack Lowlands, USA.

Department of Geological Sciences,

University of Maine,

EdWARD S. GREW

Orono, ME 04469, USA

Martin G. Yates

Geology Department, Zinc Corporation of America, Mining Division, Balmat, NY 13609, USA

WILliam DELORRAINE 